\title{
Factor VII-Targeted Photodynamic Therapy for Breast Cancer and Its Therapeutic Potential for Other Solid Cancers and Leukemia
}

\author{
Zhiwei Hu \\ Department of Obstetrics, Gynecology E Reproductive Sciences, \\ Yale University School of Medicine, New Haven, \\ U.S.A.
}

\section{Introduction}

Photodynamic therapy (PDT) is a treatment (Castano et al., 2006; Gomer, 1989; Oleinick and Evans, 1998) that involves three components: a photoactivatable photosensitizer (PS), laser light, and tissue oxygen. The current applications of non-targeted PDT (ntPDT) involve intravenous injection or topical application of PS followed by irradiation of the diseased lesion with a laser light. Upon activation by laser light, PS converts intracellular oxygen to singlet oxygen ions, which then cause cellular necrosis and/or apoptosis. PDT has clinical indications in the treatment of localized cancers, such as breast cancer, and has therapeutic potential for local recurrence of chemoresistant tumors (Capella and Capella, 2003; Merlin et al., 2003). However, a serious limitation of conventional ntPDT is the toxicity that results from internalization of the PS by normal cells (Taber et al., 1998). To overcome the poor selectivity of PS, antibodies, ligands and peptides have been tested in order to develop targeted PDT (tPDT), which would target PS into tumor cells (Mayo et al., 2003; Sharman et al., 2004) or vascular endothelial cells alone (Bechet et al., 2010). To the best of our knowledge, there are no other published papers reporting the successful development of tPDT that can simultaneously target both the tumor neovasculature and tumor cells except for three recent articles (Duanmu et al., 2011; $\mathrm{Hu}$ et al., 2010, 2011) from our laboratory (Figure 1). Here we summarize the development, efficacy and safety tests of dual tumor neovasculature- and tumor cell-targeting PDT by targeting the receptor tissue factor (TF) using its natural ligand factor VII (fVII)conjugated photoactivable sensitizers for treatment of breast cancer in preclinical studies. We also review the selective expression of $\mathrm{TF}$ on angiogenic tumor vasculature and the percentages of TF on cancer cells in several most common solid tumors and leukemia, which we believe could help us to predict what percentage of patients with individual cancer can benefit from these TF-targeting therapies in future clinical trials and applications.

\section{Targeting tumor neovasculature, tumor cells or both for development of targeted therapeutics}

It is believed that targeting tumor neovasculature is a better strategy for cancer therapy than targeting cancer cells alone for the following reasons (Alessi et al., 2004; Folkman, 1971; Romanque et al., 2008): 
i. Accessibility -- Tumor vascular endothelial cells (VECs) are accessible to therapeutic agents in blood circulation.

ii. Effectiveness -- It is estimated that each individual tumor VEC provides nutrition and oxygen to about 50-100 tumor cells.

We believe that targeting both the tumor neovasculature and tumor cells can achieve a better effect than targeting either of these types of cells alone (Hu and Garen, 2000, 2001; Hu and $\mathrm{Li}, 2010$; $\mathrm{Hu}$ et al., 2010, 2011; Hu et al., 1999). The key to successful development of therapeutics with this ability to "kill two birds with one stone" is to identify a common but specific target molecule on cancer cells and tumor angiogenic VECs (Duanmu et al., 2011; Hu et al., 2010, 2011).

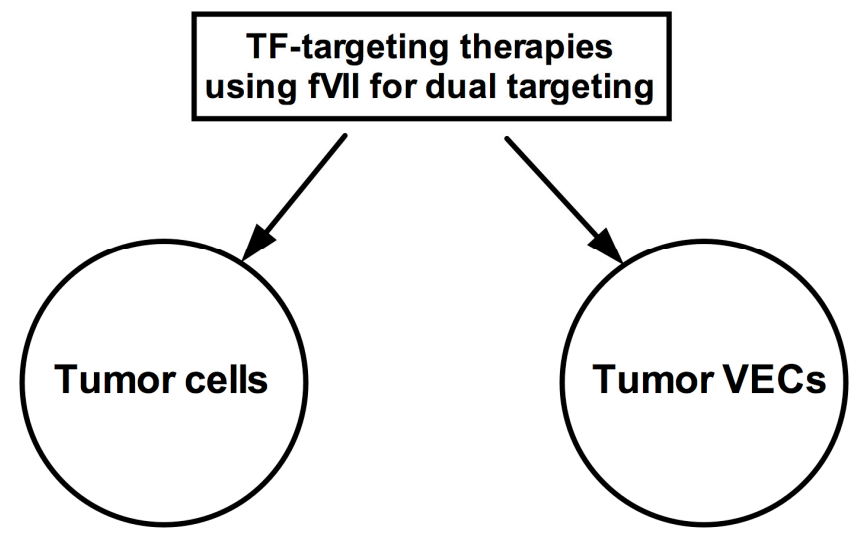

Fig. 1. Tissue factor (TF)-targeting therapies such as factor VII-targeted photodynamic therapy (fVII-tPDT) can simultaneously target both the tumor cells and tumor vascular endothelial cells (VECs) in the treatment of breast cancer with therapeutic potentials for other solid cancers and leukemia.

\section{Key points for the successful development of tumor neovasculature- and tumor cell-targeting PDT (tPDT)}

The bottleneck for the development of tPDT with the ability to target the tumor neovasculature and tumor cells is to identify a target molecule that is selectively expressed on both angiogenic VECs and tumor cells. Other key requirements are (i) the identification of a targeting vehicle that can specifically bind the target molecule and be internalized by the diseased cells and (ii) the ability to covalently conjugate this vehicle to a photosensitizer without affecting its binding activity or the photoactivity of the photosensitizer. Macromolecules such as antibodies or ligands are frequently used as targeting vehicles (Mayo et al., 2003; Sharman et al., 2004). In this regard, we chose the receptor tissue factor (TF) as the target molecule and its ligand, coagulation factor VII (fVII), as the targeting vehicle for the development of fVII-targeted Sn(IV) chlorine e6 (SnCe6) or verteporfin (VP) PDT for treatment of breast cancer in preclinical studies (Hu et al., 2010, 2011). 


\section{Tissue factor and vascular endothelial growth factor (VEGF) in tumor angiogenesis}

Tumor angiogenesis is the formation of new capillary blood vessels in tumor tissues from existing blood vessels in adjacent normal tissues (Carmeliet and Jain, 2000; McDonald and Choyke, 2003). Tumor angiogenesis is required for the tumor to grow to over microscopic size and to metastasize (Abe, 2008; Blood and Zetter, 1990; Bohle and Kalthoff, 1999; Ellis, 2004; Folkman, 2002; Rouhi et al., 2010; Weidner et al., 1991; Zetter, 1998). Tumor capillary blood vessels are quite different from normal capillary vessels in many aspects, including morphology (typically, they lack tight conjunctions between endothelial cells and even lack endothelial cells on the vessel wall, which forms holes) and permeability. The difference of the morphology of tumor blood vessels is probably due to the expression of novel molecules on the inner endothelial layer of tumor blood vessels, which do not express on the quiescent, resting endothelial cells of normal blood vessels. Identifying these novel molecules on tumor VECs can aid in developing novel therapeutic agents to specifically target tumor blood vessels for novel cancer therapy.

Cell membrane receptor tissue factor (TF) is one such novel protein that is selectively expressed on VECs in the context of pathological angiogenesis in cancer (Contrino et al., 1996; Duanmu et al., 2011; Hu and Garen, 2001; Hu et al., 1999; Takano et al., 2000), wet form macular degeneration (Bora et al., 2003; Tezel et al., 2007) and endometriosis (Krikun et al., 2010). TF is a transmembrane receptor (Fisher et al., 1987; Konigsberg and Nemerson, 1988; Morrissey et al., 1987; Spicer et al., 1987), which forms an exceptionally strong and specific complex with its natural ligand, fVII (Idusogie et al., 1996a; Idusogie et al., 1996b; O'Hara et al., 1987), as the initial step of the coagulation pathway (Spicer et al., 1987). A known molecule connecting TF to tumor angiogenesis is VEGF. VEGF is a key pro-angiogenic factor that is produced by cancer cells (Abe et al., 1999; Lacal et al., 2000). As indicated in its former name vascular permeability factor (VPF) (Watanabe et al., 1997), VEGF results in the formation of immature, leaky and twisted blood vessels in tumors (Carmeliet and Jain, 2000; McDonald and Choyke, 2003). Importantly, VEGF can induce TF expression on VECs in vitro and in vivo (Armesilla et al., 1999; Hu et al., 2010, 2011; Schabbauer et al., 2007; Shen et al., 2001; Takano et al., 2000; Zucker et al., 1998), which do not normally express TF under physiological conditions (Contrino et al., 1996; Hu et al., 1999; Osterud, 1997; Rao and Pendurthi, 1998; Semeraro and Colucci, 1997).

\section{TF is a common but specific target molecule on tumor VECs and tumor cells for development into novel tPDT as a dual-action therapeutic}

\subsection{TF is selectively expressed by angiogenic VECs in tumor but not by normal resting VECs in normal organs/tissues}

Using tumor tissues from patients and mice, Contrino and colleagues (Contrino et al., 1996) and our groups (Duanmu et al., 2011; Hu and Garen, 2001; Hu et al., 1999) separately showed that TF was selectively expressed on angiogenic VECs, such as those in the tumor neovasculature of human breast cancer samples from patients (Contrino et al., 1996) and of human melanoma tumor xenografts in mice (Hu and Garen, 2001; Hu et al., 1999). In contrast, normal quiescent VECs do not express TF (Contrino et al., 1996; Hu and Garen, 2001; Osterud, 1997; Rao and Pendurthi, 1998; Semeraro and Colucci, 1997). Moreover, we very recently show that TF is also expressed by tumor VECs in multidrug resistant human breast tumor xenograft in mice (Duanmu et al., 2011). We conclude that TF is selectively expressed by angiogenic tumor VECs in tumors including multidrug resistant tumors. 
Selective expression of TF by angiogenic VECs is similarly observed in vitro. Using VECs isolated from human umbilical vein vessels (HUVECs), we (Hu et al., 2010, 2011) and other groups (Camera et al., 1999; Zucker et al., 1998) have shown that TF is selectively expressed on VEGF-stimulated angiogenic HUVECs but not on unstimulated HUVECs.

\subsection{TF is also over-expressed by many types of cancer cells including solid cancer and leukemia (Table 1)}

Early studies indicated that TF was expressed by cancer cells in solid cancer (Callander et al., 1992) and leukemia (Andoh et al., 1987; Bauer et al., 1989). There are now numerous elegant reviews on the role of TF expression in cancer and tumor angiogenesis (Fernandez and Rickles, 2002; Milsom and Rak, 2008; Rak et al., 2006; Rak et al., 2008; Rickles and Brenner, 2008; Rickles et al., 2003; Ruf and Mueller, 1996; Ruf et al., 2010; Semeraro and Colucci, 1997). We summarize TF expression percentages by cancer cells in several most common solid cancers (Table 1) and leukemia as examples to indicate what percentage of patients with each individual cancer can potentially benefit from TF-targeting therapies in the future clinical trials and applications.

\begin{tabular}{|c|c|c|c|c|}
\hline Type of tumor & Case number & $\%$ on $\mathrm{TC}$ & $\%$ on TVEC & References \\
\hline \multirow{4}{*}{ Breast cancer } & 115 & $81 \%$ & ND & (Sturm et al., 1992) \\
\hline & 7 & $100 \%$ & $100 \%$ & (Contrino et al., 1996) \\
\hline & 213 & $91 \%$ & 98.6\% (stromal cells) & (Ueno et al., 2000) \\
\hline & $\begin{array}{l}\text { Human chemoresistant } \\
\text { breast tumor xenograft } \\
\text { from mice * }\end{array}$ & + & + & $\begin{array}{l}\text { (Duanmu et al., } \\
2011 \text { ) }\end{array}$ \\
\hline \multirow{2}{*}{ Melanoma } & $\begin{array}{l}41 \text { primary } \\
42 \text { metastatic } \\
\end{array}$ & $\begin{array}{l}95 \% \\
100 \% \\
\end{array}$ & ND & $\begin{array}{l}\text { (Kageshita et al., } \\
2001)\end{array}$ \\
\hline & $\begin{array}{l}\text { Human melanoma } \\
\text { xenograft from mice * }\end{array}$ & + & + & (Hu et al., 1999) \\
\hline \multirow{4}{*}{ Lung cancer } & 25 & $28 \%$ & $\begin{array}{l}\text { 78\% (stromal } \\
\text { macrophages, VECs) }\end{array}$ & (Shoji et al., 1998) \\
\hline & 191 (NSCLC) & $43 \%$ & ND & $\begin{array}{l}\text { Koomagi and Volm, } \\
1998)\end{array}$ \\
\hline & 55 & $80 \%$ & ND & (Sawada et al., 1999) \\
\hline & 50 & $88 \%$ & ND & (Wang et al., 2005) \\
\hline \multirow{2}{*}{$\begin{array}{l}\text { Hepatocellular } \\
\text { carcinoma (HCC) }\end{array}$} & 58 & $100 \%$ & ND & (Poon et al., 2003) \\
\hline & 62 & $63 \%$ & ND & (Kaido et al., 2005) \\
\hline \multirow[b]{3}{*}{$\begin{array}{l}\text { Pancreatic } \\
\text { cancer }\end{array}$} & 55 & $53 \%$ & $\begin{array}{l}\text { TF not in normal } \\
\text { pancreas }\end{array}$ & (Kakkar et al., 1995a) \\
\hline & 113 & $88.4 \%$ & ND & (Nitori et al., 2005) \\
\hline & \begin{tabular}{|l|}
240 \\
$(10$ normal pancreas \\
70 intraductal papillary \\
mucinous neoplasms \\
40 pancreatic \\
intraepithelial neoplasia, \\
130 resected or \\
metastatic pancreatic \\
adenocarcinomas)
\end{tabular} & $\begin{array}{l}87.9 \% \text { overall } \\
\text { (77\% pancreatic } \\
\text { intraepithelial } \\
\text { neoplasias } \\
91 \% \text { intraductal } \\
\text { papillary mucinous } \\
\text { neoplasms } \\
89 \% \text { pancreatic cancers) }\end{array}$ & $\begin{array}{l}\text { ND } \\
\text { (TF not in normal } \\
\text { pancreas) }\end{array}$ & (Khorana et al., 2007) \\
\hline
\end{tabular}




\begin{tabular}{|c|c|c|c|c|}
\hline \multirow{3}{*}{$\begin{array}{l}\text { Colorectal } \\
\text { cancer }\end{array}$} & $\begin{array}{l}67 \text { primary, of which } \\
18 \text { with liver metastasis }\end{array}$ & $\begin{array}{l}46 \% \text { of primary, } \\
88.9 \% \text { of liver metastasis }\end{array}$ & ND & $\begin{array}{l}\text { (Shigemori et al., } \\
1998)\end{array}$ \\
\hline & 100 & $57.0 \%$ & ND & $\begin{array}{l}\text { (Nakasaki et al., } \\
2002 \text { ) }\end{array}$ \\
\hline & 50 & $100 \%$ & ND & (Altomare et al., 2007) \\
\hline \multirow{4}{*}{ Prostate cancer } & 67 & $73 \%$ & ND & $\begin{array}{l}\text { (Abdulkadir et al., } \\
2000)\end{array}$ \\
\hline & 73 & $75.3 \%$ & ND & (Akashi et al., 2003) \\
\hline & $\begin{array}{l}32 \text { early stage } \\
22 \text { advanced stage }\end{array}$ & $\begin{array}{l}78 \% \text { early-stage } \\
60 \% \text { advanced stage }\end{array}$ & $\begin{array}{l}\text { ND } \\
\text { (TF not in benign } \\
\text { prostate gland) }\end{array}$ & (Kaushal et al., 2008) \\
\hline & $\begin{array}{l}\text { Human prostate tumor } \\
\text { in mice ** }\end{array}$ & + & + & $\begin{array}{l}\text { (Hu and Garen, } \\
2001)\end{array}$ \\
\hline Ovarian cancer & 32 & $84 \%$ & ND & (Uno et al., 2007) \\
\hline \multirow{3}{*}{ Glioma } & $\begin{array}{l}44 \\
(10 \text { benign gliomas } \\
14 \text { anaplastic } \\
\text { astrocytomas } \\
20 \text { glioblastomas })\end{array}$ & $\begin{array}{l}75 \% \text { overall } \\
(10 \% \text { in Grade I-II, } 86 \% \\
\text { in grade III } 95 \% \text { in grade } \\
\text { IV) }\end{array}$ & ND & $\begin{array}{l}\text { (Hamada et al., } \\
1996)\end{array}$ \\
\hline & \begin{tabular}{|l}
68 \\
$(23$ glioblastomas \\
13 anaplastic \\
astrocytomas \\
32 low-grade \\
astrocytomas)
\end{tabular} & $\begin{array}{l}47 \% \text { overall } \\
\text { (91.3\% glioblastomas, } \\
46.2 \% \text { anaplastic } \\
\text { astrocytomas, and } 15.6 \% \\
\text { low-grade } \\
\text { astrocytomas) }\end{array}$ & \begin{tabular}{|l}
$44 \%$ overall \\
$(73.9 \%$ \\
glioblastomas, \\
$53.8 \%$ anaplastic \\
astrocytomas, \\
$0 \%$ low grade \\
astrocytomas) \\
\end{tabular} & (Takano et al., 2000) \\
\hline & $\begin{array}{l}34 \text { gliomas } \\
5 \text { normal brain tissues }\end{array}$ & $\begin{array}{l}58.8 \% \text { overall } \\
(20 \% \text { of grade I } \\
43 \% \text { of grade II, } \\
58 \% \text { of grade III } \\
90 \% \text { of grade IV) }\end{array}$ & $\begin{array}{l}\text { ND } \\
\text { (TF not in normal } \\
\text { brain tissues) }\end{array}$ & (Guan et al., 2002) \\
\hline
\end{tabular}

\section{Notes:}

Abbreviations: ND, not determined; TC, tumor cells; TVEC, tumor vascular endothelial cells; NSCLC, non-small cell lung cancer; HCC: hepatocellular carcinoma.

* Human breast and melanoma tumor xenografts were removed from mice and paraffin or frozen sections were made and immunohistochemically stained for endothelial TF by using a rabbit polyclonal anti-mouse TF antibody (Duanmu et al., 2011) and murine fVII/human IgG1 Fc protein (mouse Icon) (Hu et al., 1999), respectively.

** Mouse Icon protein was intravenously injected into the SCID mice carrying subcutaneous human prostate tumor xenografts and the bio-distribution of mouse Icon protein was studied by immunofluorescence staining for the human IgG1 Fc of the mouse Icon protein using an FITCconjugated anti-human IgG antibody (Hu and Garen, 2001).

+ TF expression was positively detected.

Table 1. TF expression in breast cancer and other solid cancers.

\subsubsection{TF in $\mathbf{8 0 - 1 0 0 \% ~ o f ~ b r e a s t ~ c a n c e r ~}$}

TF is expressed by breast cancer cell lines and breast cancer cells in tumor tissues (Contrino et al., 1996; Duanmu et al., 2011; Hu et al., 2010, 2011; Sturm et al., 1992; Ueno et al., 2000). Sturm et al. (Sturm et al., 1992) reported that $81 \%$ (93 out of 115) breast cancer tissues were TF expression positive on tumor cells. Contrino et al. (Contrino et al., 1996) further showed 
that TF was localized on vascular endothelial cells (VEC) and tumor cells within tumors from all $7(100 \%)$ invasive breast cancer cases but not in the VEC or tumor cells of benign tumors from 10 patients with fibrocystic disease of the breast. Ueno et al. (Ueno et al., 2000) showed that 91\% (193 cases) of 213 breast cancer tissues were positive for TF expression, which was detected on tumor cells, fibroblasts, monocytes and vascular endothelial cells in the tumor tissues. Taking together, TF expression was indeed detected on tumor cells and tumor vascular endothelial cells in $80-100 \%$ of breast tumors.

\subsubsection{TF in $95-100 \%$ of melanoma}

TF is over-expressed by melanoma cancer cells (Bromberg et al., 1995; Hu and Garen, 2000; $\mathrm{Hu}$ et al., 1999). Particularly Kageshita et al. reported that TF expression was detected in $95 \%$ of primary and $100 \%$ of metastatic melanoma tumor tissues from 41 and 24 patients, respectively (Kageshita et al., 2001).

\subsubsection{TF in $\mathbf{4 0 - 8 0 \% ~ o f ~ l u n g ~ c a n c e r ~}$}

TF is expressed in human lung cancer cell lines (Keller et al., 2001; Minamiya et al., 2004; Rauch et al., 2005; Salge et al., 2001; Zacharski et al., 1983) as well as in about 40-80\% of human lung tumor tissues from patients worldwide (Koomagi and Volm, 1998; Sawada et al., 1999; Shoji et al., 1998; Wang et al., 2005). Shoji et al. (Shoji et al., 1998) reported that TF expression on stromal macrophage and vascular endothelial cells was detected in 76\% (19 out of 25) of lung cancer patients, while lung cancer TF expression was detected in only $28 \%$ of these patients. Koomagi and Volm (Koomagi and Volm, 1998) reported that 75 of 175 cases $(42.8 \%)$ with non-small-cell lung carcinomas (NSCLC) in Germany were TF positive and a significant association was found between TF expression and microvessel density. Sawada et al (Sawada et al., 1999) reported that TF was detected in NSCLC cell lines and in 46 of 55 specimens (80\%) of surgically resected NSCLC tumors in Japan. Wang et al (Wang et al., 2005) reported that $88 \%$ of 50 human NSCLC tumors overexpressed TF in the United States.

\subsubsection{TF in $63-100 \%$ of hepatocellular carcinoma (HCC)}

Our unpublished study showed that TF is expressed by HCC SNU-423 line and human hepatoblastoma Hep G2 line. SNU-423 is a human HCC line with chemoresistance from a 40 years old male patient (Park et al., 1995). Hep G2 was isolated from a child (Aden et al., 1979; Knowles et al., 1980) and was recently re-characterized as hepatoblastoma (LopezTerrada et al., 2009). TF is also over-expressed by the cancer cells in HCC tumor tissues (Kaido et al., 2005; Poon et al., 2003). Poon et al reported in 2003 that TF expression was detected in 58 of 58 patients (100\%) with HCC in Hong Kong, China and that TF expression level correlated significantly with tumor microvessel density $(p=0.002)$, an indicator for tumor angiogenesis (Poon et al., 2003). Kaido et al reported in a retrospective study in 2005 that 39 of 62 Japanese patients with HCC, who survived for more than 5 years after surgery, were TF positive (62.9\%) and had higher recurrence rate (Kaido et al., 2005). They concluded that TF expression was closely associated with tumor invasion and metastasis, and might serve as a prognostic factor of recurrence in HCC (Kaido et al., 2005). These two reports showed that TF was expressed in $\sim 63 \%$ or even $100 \%$ of Japanese and Chinese patients with HCC, respectively. However, both papers did not investigate the TF expression on tumor VECs. So far there are no published papers reporting the percentage of TF expression in the US patients with HCC. 


\subsubsection{TF in $53-90 \%$ of pancreatic cancer}

Several groups showed that TF expression was found on pancreatic cancer tissues or cell lines (Cohen and Burtness, 2006; Haas et al., 2006; Hobbs et al., 2007; Iijima et al., 1991; Kakkar et al., 1995a; Kakkar et al., 1995b; Khorana et al., 2007; Khorana and Fine, 2004; Lindahl et al., 1993; Lindahl et al., 1992; Nitori et al., 2005; Silberberg et al., 1989; Taniguchi et al., 1998; Tesselaar et al., 2007; Ueda et al., 2001), but not in normal pancreatic cells (Cohen and Burtness, 2006; Kakkar et al., 1995a). Kakkar et al. in 1995 reported that TF expression was detected in 29 of 55 (53\%) pancreatic tumors (Kakkar et al., 1995a). They found that TF expression was significantly correlated with the histological grade of the tumors, i.e., the poorer the differentiation of the tumor, the more expression of TF. Moreover, Kakkar et al. reported that TF was not detected in all of 18 normal human pancreas tissues (Kakkar et al., 1995a), indicating that TF was specifically expressed on pancreatic tumor cells in the pancreas. Nitori et al. in 2005 confirmed the observation of TF expression on pancreatic tumors (Nitori et al., 2005). They reported that $88.4 \%$ of 113 Japanese patients with pancreatic ductal adenocarcinoma were TF positive on cancer cells, and that increased TF expression was significantly correlated with the extent of the primary tumor, lymph node metastasis, lymphatic distant metastasis, advanced tumor-node-metastasis stage, and high tumor grade. Therefore, they concluded that TF expression on tumor cells was a predictor for survival. Recently, Khorana et al. reported that TF was expressed in $77 \%$ pancreatic intraepithelial neoplasias, $91 \%$ intraductal papillary mucinous neoplasms, and $89 \%$ pancreatic cancers, but not in normal pancreas (Khorana et al., 2007). High TF expression was associated with high level of VEGF and increased microvessel density. Therefore they stated that "TF represents an attractive and novel therapeutic target in pancreatic cancer, and anti-TF approaches deserve further study in this setting" (Khorana et al., 2007). All of these previous studies indicated that TF indeed could serve as a therapeutic target on pancreatic cancer cells (and probably on tumor neovasculature) in pancreatic cancer for TFtargeting therapies in the treatment of this intractable cancer.

\subsubsection{TF in $\mathbf{5 7 - 1 0 0 \% ~ o f ~ c o l o r e c t a l ~ c a n c e r ~}$}

Shigemori et al. (Shigemori et al., 1998) reported that TF was detected in 57\% of colorectal cancer from 79 patients, and its expression was significantly increased $(\mathrm{p}=0.01)$ in metastatic tumors $(88 \%)$ from 17 patients. Later, Nakasaki et al. reported the same percentage $(57 \%)$ of TF expression in 100 colorectal cancer tissues (Nakasaki et al., 2002). Using ELISA, Altomare et al. (Altomare et al., 2007) detected higher TF expression (100\%) in 50 surgical colorectal cancer specimens.

\subsubsection{TF in $\mathbf{6 0 - 7 8 \%}$ of prostate cancer}

TF expression was detected in urological cancers including renal cell carcinoma, bladder cancer and prostate cancer (Akashi et al., 2003; Forster et al., 2003; Kaushal et al., 2008; Langer et al., 2007; Lwaleed et al., 2000; Nieva, 2007; Ohta et al., 2002). Abdulkadir et al. (Abdulkadir et al., 2000) reported that TF expression was detected on the epithelial cells of malignant glands $(73 \% ; \mathrm{n}=67)$ of prostate cancer specimens, and TF expression was significantly correlated with tumor angiogenesis and preoperative level of prostate specific antigen. Similarly, Kaushal et al. (Kaushal et al., 2008) reported that TF expression was positively stained in malignant gland in $78 \%$ specimens of early-stage and $60 \%$ of specimens of advanced stage prostate cancer, but not in the benign gland. TF was also detected in $75.3 \%$ of metastatic prostate cancer from patients (Akashi et al., 2003). 


\subsubsection{TF in gynecological cancers}

TF is also over-expressed by ovarian cancer cells (Chinen et al., 2009; Uno et al., 2007; Yokota et al., 2009). Particularly, when Uno et al. studied the TF expression as a possible determinant of thromboembolism in ovarian cancer, they found that TF was over-expressed on the ovarian cancer cells in 27 out of 32 ovarian cancer patients (84\%) by immunohistochemical staining (Uno et al., 2007). However, tumor endothelial TF in ovarian cancer and other gynecological cancers remains to be investigated. In addition, our unpublished studies showed that TF was expressed by human ovarian cancer lines OVCAR5 and Hey and cervical cancer line HeLa.

\subsubsection{TF in brain cancer}

Hamada and co-workers studied the TF expression in surgical specimens of glioma in 1996 (Hamada et al., 1996). They showed that 75\% gliomas were positive for TF, with a correlation of malignancy grade (1 of 10 benign gliomas (10\%) in malignancy Grade I-II, 13 of 14 anaplastic astrocytomas (86\%) in malignancy grade III and 19 of 20 glioblastomas $(95 \%)$ in malignancy grade IV. Takano and co-workers (Takano et al., 2000) reported that TF antigen was detected in the brain tumor cells of 21 out of 23 glioblastomas, 6 of 13 anaplastic astrocytomas, and 5 of 32 low-grade astrocytomas, indicating that TF was expressed by $47 \%$ (32/68) of glioma patients. Importantly, TF antigen was also detected in the tumor-associated vessels of 17 out of 23 glioblastomas, 7 of 13 anaplastic astrocytomas, and none of 32 low grade astrocytomas. Later, Guau et al. (Guan et al., 2002) also investigated the expression of TF in 5 normal brain tissues and 32 glioma tissues from Chinese patients, and the glioma cell line U251. They similarly showed that the higher grade, the more TF expression (90\% of the grade IV cases, $58 \%$ of grade III, $43 \%$ of grade II, and $20 \%$ of grade I). Importantly they showed that TF expression was not detected in any of 5 normal brain tissues, indicating that TF expression could be a specific biomarker in brain tumor.

\subsubsection{TF in leukemia}

Leukemia is a malignant neoplasm of hematopoietic tissue originating in the bone marrow and infiltrating the peripheral blood and often also the spleen, liver, and lymph nodes. Acute leukemia, including AML and ALL are characterized by proliferation of immature cells or blasts. If untreated, death usually occurs within 6 months in most cases. It was reported that TF is expressed on the human leukemic HL-60 (Freeburn et al., 1995; Hair et al., 1996; Kubota et al., 1991; Rickles et al., 1995; Tanaka et al., 1989), Molt-4 (Tanaka, 1989), THP-1 (Tanaka, 1989) cell lines, and on leukemic cells from patients with AML (Andoh et al., 1987; Bauer et al., 1989; Nakasaki et al., 2000b; Tanaka et al., 1989; Tanaka and Kishi, 1990; Tanaka and Yamanishi, 1993) and ALL (Kubota et al., 1991; Nakasaki et al., 2000a). TF is not expressed on the normal peripheral mononuclear cells unless stimulated by endotoxin or other cytokines (Rickles et al., 1995), nor on myeloid precursor cells (Bauer et al., 1989). TF was also detected in the plasma of patients with leukemia (Kubota et al., 1991; Nakasaki et al., 2000a) and in HL-60 culture medium (Kubota et al., 1991). The evidence for TF expression on proliferating leukemic cells identifies leukemia as a potential candidate for TF-targeting therapies.

Another target in leukemia patients for TF-targeting therapy is the bone marrow vascularity (Yang and Han, 2002). Angiogenesis does occur in leukemia (Aguayo et al., 2000; Dickson 
and Shami, 2001; Hussong et al., 2000; Korkolopoulou et al., 2003; Litwin et al., 2002; Padro et al., 2000; Perez-Atayde et al., 1997; Pule et al., 2002). Microvessel density is increased in bone marrow biopsies obtained from patients with childhood ALL (Aguayo et al., 2000; Dickson and Shami, 2001), and in bone marrow of newly diagnosed AML patients (Padro et al., 2000). Further indication of leukemia-associated angiogenesis is an increased level of vascular endothelial growth factor (VEGF) in bone marrow blast cells of AML patients (Litwin et al., 2002). These findings have led to tests of anti-angiogenic therapy for leukemia (Thomas et al., 2001). VEGF induces TF expression on vascular endothelial cells (Hu et al., 2010, 2011; Zucker et al., 1998) and therefore also could induce TF expression in the tumor neovasculature in bone marrow of leukemia patients (to be investigated), providing an additional target for TF-targeting therapies including Icon immunotherapy (Hu and Garen, 2000, 2001; Hu and Li, 2010; Hu et al., 1999) and fVII-targeted PDT (Duanmu et al., 2011; Hu et al., 2010, 2011).

\subsubsection{TF on normal cells is sequestered by semi-permeable vessel walls}

Although TF is a normal cell surface receptor (Morrissey et al., 1987; Spicer et al., 1987) and is expressed defensively on extravascular cells of several normal tissues and in the adventitial layer of the blood vessel wall (readily to initiate coagulation cascade upon the damage to vessel wall integrity), it is sequestered from direct contact with circulating fVII at a low concentration $(10 \mathrm{nM})$ at these sites by the tight endothelial cell layer of the normal vasculature (Osterud, 1997; Rao and Pendurthi, 1998; Semeraro and Colucci, 1997). In contrast, newly formed tumor capillary blood vessels are leaky because they lack tight junctions between endothelial cells, and their walls may even lack endothelial cells entirely (Carmeliet and Jain, 2000; McDonald and Choyke, 2003). Thus, only the TF on angiogenic VECs and tumor cells is accessible to TF-targeting therapeutic agents via leaky tumor blood vessels.

Based on its selective expression and the leakiness of tumor neovasculature, TF is regarded as a common but specific target molecule in tumor blood vessels and cancer cells for the development of novel neovasculature- and cancer cell-targeting therapies, such as fVIItargeted PDT (fVII-tPDT) (Duanmu et al., 2011; Hu et al., 2010, 2011).

\section{Successful development of fVII-tPDT by targeting TF for simultaneous, selective and effective killing of angiogenic VECs and breast cancer cells}

As reported in our three recent published studies, we have chosen the receptor TF as a target molecule and its ligand, fVII, as a targeting vehicle for the development of ligandtargeted PDT and have successfully developed fVII-targeted PDT using fVII-SnCe6 or fVIIVP conjugates for treatment of breast cancer (Duanmu et al., 2011; Hu et al., 2010, 2011) and wet macular degeneration (Lu et al., 2009). We showed that TF as the target molecule and fVII as the targeting vehicle met all of the requirements for successful development of a dual-action tPDT, as discussed below.

\subsection{Identification of a targeting vehicle that can specifically bind the target molecule and be internalized by the diseased cells}

We identified fVII as the targeting vehicle to bind the target molecule TF. The reason for choosing the natural ligand $\mathrm{fVII}$ for $\mathrm{TF}$, instead of antibodies to TF, is that the dissociation 
constant (Kd) for fVII binding to TF (pM level) is about 100-1000 fold lower than those of antibodies to TF (nM levels), i.e., the affinity for fVII to TF is 100-1000 fold higher that antibodies to TF, and that fVII can be made in human sequence without need for humanization process (Hu and Li, 2010; Hu et al., 2010, 2011).

Regarding the ability of fVII to internalize into cells, Rao and colleagues had shown that wild-type human fVII protein could be endocytosed by TF-transfected baby hamster kidney cells (Hansen et al., 2001). But it was unknown if fVII with a coagulation active site mutation (K341A) can be internalized into cells, which was a key process for successful development of tPDT in order for the targeting vehicle fVII to internalize the covalentlyconjugated photosensitizer into the target cells. Using co-localization of an intracellular Factin cytoskeleton with a fVII(K341A)/human IgG1 Fc Icon immunoconjugate, which contained an fVII peptide containing a K341A mutation fused to the Fc portion of an IgG1 antibody for cancer immunotherapy (Hu and Garen, 2000, 2001; $\mathrm{Hu}$ and Li, 2010; Hu et al., 1999), we showed that fVII with K341A mutation could be endocytosed into breast cancer cells and VEGF-stimulated angiogenic HUVEC with a maximal detection of intracellular fVII at 30 min after binding (Hu et al., 2011) (confocal imagings at other time points were not shown). Thus we conclude that fVII(K341A) as the targeting vehicle can specifically bind its cognate receptor $\mathrm{TF}$, the target molecule, and be internalized by the diseased cells.

\subsection{The ability to covalently conjugate fVII as the targeting vehicle to a photosensitizer without affecting its binding activity or the photoactivity of the photosensitizer}

To covalently conjugate fVII protein with photosensitizers verteporfin and Sn IV chlorin e6 (SnCe6), we used the cross linker EDC with the ability to bind to - $\mathrm{COOH}$ groups on photosensitizers and then to -NH2 groups on protein molecules (Hu et al., 2010, 2011). In principle, this procedure using EDC can be used to conjugate fVII proteins to any other photosensitizers that have - $\mathrm{COOH}$ groups. We tested two photosensizers that have $\mathrm{COOH}$ groups, namely verteporfin $(689 \mathrm{~nm})$ and SnCe6 $(635 \mathrm{~nm})$. At the time when we carried out the study reported in (Hu et al., 2010), the chemically pure form of verteporfin was not commercially available to us. Now both SnCe6 and VP can be synthesized and commercially available in chemically pure form. It is worth noting that SnCe6 is stable at $4^{\circ} \mathrm{C}$ for at least one year without any loss of its photoactivity to cancer cells (when it was prevented from light. See supplementary information in ref. (Hu et al., 2011)). Since we used excess photosensitizer in the chemical reaction, we used size exclusion spin columns (Sephadex G50) to separate the unconjugated photosensitizers (being hold in the column resin) from the fVII-conjugated photosensitizer (being collected in the collection tubes after spin).

Using breast cancer cell-ELISA and flow cytometry assays, we showed that the binding activity of fVII in the photosensitizer conjugate either with verteporfin or with SnCe6 was retained (Hu et al., 2010, 2011). To address the photoactivity of fVII-PS conjugate, we used a crystal violet staining for the loss of monolayer membrane to determine the effect of PDT on killing cancer cells and compared to ntPDT in vitro. We showed that TF-targeting PDT by fVII enhanced 3-4 fold the effect of verteporfin PDT (Hu et al., 2010) and 12-13 fold of SnCe6 PDT (Hu et al., 2011) on killing breast cancer cells in vitro. The reason for the less effect of fVII-verteporfin PDT was probably because chemically pure verteporfin (Benzoporphyrin 
derivative-monacid ring A, BPD-MA) was not available to us so we had to extract it from its commercial formula Visudyne (QLT Inc) and the extracts still might contain trace of other components that might interfere with the killing effect, whereas SnCe6 was available in chemically pure form (Frontier Scientific, Logan, UT). We conclude that covalent conjugation reaction did not affect the binding activity of fVII and the photoactivity of the photosensitizer in the fVII-photosensitizer conjugates.

Interestingly, we observed that fVII-tPDT, either with fVII-verteporfin or with fVII-SnCe6, reached the maximal killing effect on a variety of cancer cells in vitro for drug-laser light interval at $90 \mathrm{~min}$ (Hu et al., 2010, 2011), whereas the maximal intracellular localization of $\mathrm{fVII} / \mathrm{TF}$ reached at $30 \mathrm{~min}$ after incubation of fVII/Fc with target cells (Hu et al., 2011).

\subsection{The selectivity of fVII-tPDT for cancer cells and angiogenic VECs}

In order to test whether fVII-tPDT is selective on killing cancer cells and has no adverse effects on normal cells that do not express TF, we use a high (MDA-MB-231) and a low (MCF7) TF breast cancer cell lines and a normal human embryonic kidney 293 cells as a nonTF expressing line. We showed that fVII-tPDT was selectively killing both TF-expressing breast cancer cells with a TF-level dependent response, but it had no killing at all on 293 cells, indicating that this fVII-tPDT was selective and effective in killing TF-breast cancer cells.

Moreover, we used VEGF-stimulated HUVEC and unstimulated HUVEC as models of angiogenic VECs and normal, resting VECs. We showed that fVII-tPDT was able to selectively kill VEGF-stimulated angiogenic HUVEC but had no killing effect on normal, resting HUVEC (Hu et al., 2011), indicating that fVII-tPDT was also selective and effective in killing angiogenic VECs.

\subsection{Mechanism of action of fVII-tPDT}

Using the assays for Caspase-3/7 and lactate dehydrogenase (LDH) activities, we showed that fVII-tPDT, either with verteporfin or SnCe6, could induce apoptosis and necrosis right after PDT treatment (Duanmu et al., 2011; Hu et al., 2010, 2011), as the underlying mechanism.

\subsection{The effect and safety of fVII-tPDT in vivo in mouse models of breast cancer}

We tested the effect of fVII-tPDT using verteporfin or SnCe6 in three mouse models of breast cancer, the first with murine breast cancer EMT6 in immunocompetent Balb/c mice, the second with human breast tumor MDA-MD-231 in immunodeficient nude mice and the third with chemoresistant breast cancer MCF-7/MDR in nude mice. The results showed that fVII-tPDT $\left(2 \mu \mathrm{M}\right.$ SnCe6 in fVII-SnCe6 PDT for EMT6 and MDA-MB-231 $\left(72 \mathrm{~J} / \mathrm{cm}^{2}\right)$ and MCF-7/MDR $\left(65 \mathrm{~J} / \mathrm{cm}^{2}\right)$; or $2 \mu \mathrm{M}, 105 \mathrm{~J} / \mathrm{cm}^{2}$ in verteporfin PDT for EMT6) was effective in inhibiting tumor growth in mice, whereas ntPDT at the same conditions had no effect. In all three studies, there were no differences in mouse body weight, complete blood counts and differential analyses of leukocytes between the control mice and fVII-tPDT treated mice, and none of those mice had any other signs of toxicity during or at the end of the experiments (Duanmu et al., 2011; Hu et al., 2010, 2011). We thus conclude that fVII-tPDT was effective and safe in the treatment of human and murine breast tumors in mice, including chemoresistant breast tumor. 


\section{Previous studies on the development of other TF-targeting therapeutics}

In the course of the development of TF-targeting therapeutics, $\mathrm{Hu}$ and Garen reported for the first time in 1999 an antibody-like fVII-human IgG1 Fc fusion protein (Hu et al., 1999), which later was called an Icon (Hu and Garen, 2001). Icon has been tested for immunotherapy by eradicating pathological neovasculature for treatment of tumors (Cocco et al., 2010; Hu and Garen, 2000, 2001; Hu and Li, 2010; Hu et al., 1999; Tang et al., 2007) and non-cancerous diseases such as wet form macular degeneration (Bora et al., 2003; Tezel et al., 2007) and endometriosis (Krikun et al., 2010). Similar to the studies in which $\mathrm{Hu}$ and Garen introduced a mutation (K341A) in the fVII protein in order to reduce its coagulation activity, Shoji and colleagues in 2008 (Shoji et al., 2008) reported the use of an active sitechemically inactivated fVIIa (FFRck-fVIIa) as a carrier for the targeted delivery of a potent synthetic curcumin analog (EF24) to TF-expressing tumor-associated VECs and tumor cells. The study by Shoji et al. provides independent evidence in support of our previous concept and findings regarding the efficacy of TF-targeting therapeutics.

As a different TF-targeting therapeutic approach, fVII-tPDT can be used as a stand-alone modality, and potentially in combination with Icon immunotherapy, surgery, and other modality for treatment of breast cancer and potentially of other laser light-accessible tumors on skin surfaces or in the internal cavity. To further enhance the effect of fVII-tPDT, we can increase the laser irradiation time and use better photosensitizers with longer wavelength (for deeper penetration) and better laser light sources with larger irradiation area in future preclinical and clinical studies.

\section{Conclusion}

In conclusion, fVII-targeted verteporfin or SnCe6 PDT is selective and effective in killing angiogenic VECs and breast cancer cells in vitro and can significantly inhibit the tumor growth of murine and human breast cancer in vivo. As TF is over-expressed by many types of cancer cells, including solid cancer and leukemia, and selectively expressed by angiogenic VECs of pathological neovasculature in tumor, macular generation and endometriosis, we anticipate that fVII-tPDT will have broad therapeutic potential for breast tumor and other tumors as well as for other pathological neovasculature-associated non-cancerous diseases (including but not limited to wet macular degeneration and endometriosis), in which the diseased lesions abnormally express TF and can be accessed by laser light, for instance, delivered by optical fibers through endoscopic, interstitial, or intracavitary techniques.

\section{Acknowledgement}

The studies on fVII-tPDT were supported by CT DPH Biomedical Research Grant (RFP\#2009-0096), the Breast Cancer Alliance Exceptional Project Grant, the Susan Komen Award (BCTR0601204) and the Swebilius Translational Cancer Research Award from the Yale Cancer Center.

\section{Competing interests}

The author is a co-inventor of the US patents on Neovascular-Targeted Immunoconjugates (US patents no. 6,924,359, 7,858,092 and 7,887,809). 


\section{References}

Abdulkadir, S.A., Carvalhal, G.F., Kaleem, Z., Kisiel, W., Humphrey, P.A., Catalona, W.J., and Milbrandt, J. (2000). Tissue factor expression and angiogenesis in human prostate carcinoma. Hum Pathol 31, 443-447.

Abe, K., Shoji, M., Chen, J., Bierhaus, A., Danave, I., Micko, C., Casper, K., Dillehay, D.L., Nawroth, P.P., and Rickles, F.R. (1999). Regulation of vascular endothelial growth factor production and angiogenesis by the cytoplasmic tail of tissue factor. Proceedings of the National Academy of Sciences of the United States of America 96, 8663-8668.

Abe, R. (2008). Angiogenesis in tumor growth and metastasis. Curr Pharm Des 14, 3779.

Aden, D.P., Fogel, A., Plotkin, S., Damjanov, I., and Knowles, B.B. (1979). Controlled synthesis of HBsAg in a differentiated human liver carcinoma-derived cell line. Nature 282, 615-616.

Aguayo, A., Kantarjian, H., Manshouri, T., Gidel, C., Estey, E., Thomas, D., Koller, C., Estrov, Z., O'Brien, S., Keating, M., et al. (2000). Angiogenesis in acute and chronic leukemias and myelodysplastic syndromes. Blood 96, 2240-2245.

Akashi, T., Furuya, Y., Ohta, S., and Fuse, H. (2003). Tissue factor expression and prognosis in patients with metastatic prostate cancer. Urology 62, 1078-1082.

Alessi, P., Ebbinghaus, C., and Neri, D. (2004). Molecular targeting of angiogenesis. Biochimica et biophysica acta 1654, 39-49.

Altomare, D.F., Rotelli, M.T., Pentimone, A., Rossiello, M.R., Martinelli, E., Guglielmi, A., De Fazio, M., Marino, F., Memeo, V., Colucci, M., et al. (2007). Tissue factor and vascular endothelial growth factor expression in colorectal cancer: relation with cancer recurrence. Colorectal Dis 9, 133-138.

Andoh, K., Kubota, T., Takada, M., Tanaka, H., Kobayashi, N., and Maekawa, T. (1987). Tissue factor activity in leukemia cells. Special reference to disseminated intravascular coagulation. Cancer 59, 748-754.

Armesilla, A.L., Lorenzo, E., Gomez del Arco, P., Martinez-Martinez, S., Alfranca, A., and Redondo, J.M. (1999). Vascular endothelial growth factor activates nuclear factor of activated T cells in human endothelial cells: a role for tissue factor gene expression. Molecular and cellular biology 19, 2032-2043.

Bauer, K.A., Conway, E.M., Bach, R., Konigsberg, W.H., Griffin, J.D., and Demetri, G. (1989). Tissue factor gene expression in acute myeloblastic leukemia. Thrombosis research $56,425-430$.

Bechet, D., Tirand, L., Faivre, B., Plenat, F., Bonnet, C., Bastogne, T., Frochot, C., Guillemin, F., and Barberi-Heyob, M. (2010). Neuropilin-1 targeting photosensitizationinduced early stages of thrombosis via tissue factor release. Pharm Res 27, 468-479.

Blood, C.H., and Zetter, B.R. (1990). Tumor interactions with the vasculature: angiogenesis and tumor metastasis. Biochimica et biophysica acta 1032, 89-118.

Bohle, A.S., and Kalthoff, H. (1999). Molecular mechanisms of tumor metastasis and angiogenesis. Langenbecks Arch Surg 384, 133-140.

Bora, P.S., Hu, Z., Tezel, T.H., Sohn, J.H., Kang, S.G., Cruz, J.M., Bora, N.S., Garen, A., and Kaplan, H.J. (2003). Immunotherapy for choroidal neovascularization in a laser- 
induced mouse model simulating exudative (wet) macular degeneration. Proc Natl Acad Sci U S A 100, 2679-2684.

Bromberg, M.E., Konigsberg, W.H., Madison, J.F., Pawashe, A., and Garen, A. (1995). Tissue factor promotes melanoma metastasis by a pathway independent of blood coagulation. Proc Natl Acad Sci U S A 92, 8205-8209.

Callander, N.S., Varki, N., and Rao, L.V. (1992). Immunohistochemical identification of tissue factor in solid tumors. Cancer 70, 1194-1201.

Camera, M., Giesen, P.L., Fallon, J., Aufiero, B.M., Taubman, M., Tremoli, E., and Nemerson, Y. (1999). Cooperation between VEGF and TNF-alpha is necessary for exposure of active tissue factor on the surface of human endothelial cells. Arterioscler Thromb Vasc Biol 19, 531-537.

Capella, M.A., and Capella, L.S. (2003). A light in multidrug resistance: photodynamic treatment of multidrug-resistant tumors. J Biomed Sci 10, 361-366.

Carmeliet, P., and Jain, R.K. (2000). Angiogenesis in cancer and other diseases. Nature 407, 249-257.

Castano, A.P., Mroz, P., and Hamblin, M.R. (2006). Photodynamic therapy and anti-tumour immunity. Nat Rev Cancer 6, 535-545.

Chinen, K., Fujino, T., Horita, A., Sakamoto, A., and Fujioka, Y. (2009). Pulmonary tumor thrombotic microangiopathy caused by an ovarian cancer expressing tissue factor and vascular endothelial growth factor. Pathol Res Pract 205, 63-68.

Cocco, E., Hu, Z., Richter, C.E., Bellone, S., Casagrande, F., Bellone, M., Todeschini, P., Krikun, G., Silasi, D.A., Azodi, M., et al. (2010). hI-con1, a factor VII-IgGFc chimeric protein targeting tissue factor for immunotherapy of uterine serous papillary carcinoma. Br J Cancer 103, 812-819.

Cohen, S.J., and Burtness, B.A. (2006). Novel targets in pancreatic cancer: focus on future paths to therapy. Expert opinion on therapeutic targets 10, 771-775.

Contrino, J., Hair, G., Kreutzer, D.L., and Rickles, F.R. (1996). In situ detection of tissue factor in vascular endothelial cells: correlation with the malignant phenotype of human breast disease. Nature medicine 2, 209-215.

Dickson, D.J., and Shami, P.J. (2001). Angiogenesis in acute and chronic leukemias. Leuk Lymphoma 42, 847-853.

Duanmu, J., Cheng, J., Xu, J., Booth, C.J., and $\mathrm{Hu}$, Z. (2011). Effective treatment of chemoresistant breast cancer in vitro and in vivo by a factor VII-targeted photodynamic therapy. British journal of cancer 104, 1401-1409.

Ellis, L.M. (2004). Angiogenesis and its role in colorectal tumor and metastasis formation. Semin Oncol 31, 3-9.

Fernandez, P.M., and Rickles, F.R. (2002). Tissue factor and angiogenesis in cancer. Curr Opin Hematol 9, 401-406.

Fisher, K.L., Gorman, C.M., Vehar, G.A., O'Brien, D.P., and Lawn, R.M. (1987). Cloning and expression of human tissue factor cDNA. Thrombosis research 48, 89-99.

Folkman, J. (1971). Tumor angiogenesis: therapeutic implications. N Engl J Med 285, 11821186.

Folkman, J. (2002). Role of angiogenesis in tumor growth and metastasis. Semin Oncol 29, 15-18. 
Forster, Y., Meye, A., Albrecht, S., Kotzsch, M., Fussel, S., Wirth, M.P., and Schwenzer, B. (2003). Tissue specific expression and serum levels of human tissue factor in patients with urological cancer. Cancer Lett 193, 65-73.

Freeburn, J.C., Gilmore, W.S., and Strain, J.J. (1995). The effect of cytokines on tissue factor expression in HL-60 and U937 cell lines. Biochem Soc Trans 23, 2865.

Gomer, C.J. (1989). Photodynamic therapy in the treatment of malignancies. Semin Hematol 26, 27-34.

Guan, M., Jin, J., Su, B., Liu, W.W., and Lu, Y. (2002). Tissue factor expression and angiogenesis in human glioma. Clin Biochem 35, 321-325.

Haas, S.L., Jesnowski, R., Steiner, M., Hummel, F., Ringel, J., Burstein, C., Nizze, H., Liebe, S., and Lohr, J.M. (2006). Expression of tissue factor in pancreatic adenocarcinoma is associated with activation of coagulation. World J Gastroenterol 12, 4843-4849.

Hair, G.A., Padula, S., Zeff, R., Schmeizl, M., Contrino, J., Kreutzer, D.L., de Moerloose, P., Boyd, A.W., Stanley, I., Burgess, A.W., et al. (1996). Tissue factor expression in human leukemic cells. Leuk Res 20, 1-11.

Hamada, K., Kuratsu, J., Saitoh, Y., Takeshima, H., Nishi, T., and Ushio, Y. (1996). Expression of tissue factor correlates with grade of malignancy in human glioma. Cancer 77, 1877-1883.

Hansen, C.B., Pyke, C., Petersen, L.C., and Rao, L.V. (2001). Tissue factor-mediated endocytosis, recycling, and degradation of factor VIIa by a clathrin-independent mechanism not requiring the cytoplasmic domain of tissue factor. Blood 97, 17121720.

Hobbs, J.E., Zakarija, A., Cundiff, D.L., Doll, J.A., Hymen, E., Cornwell, M., Crawford, S.E., Liu, N., Signaevsky, M., and Soff, G.A. (2007). Alternatively spliced human tissue factor promotes tumor growth and angiogenesis in a pancreatic cancer tumor model. Thrombosis research 120 Suppl 2, S13-21.

$\mathrm{Hu}, \mathrm{Z}$. , and Garen, A. (2000). Intratumoral injection of adenoviral vectors encoding tumortargeted immunoconjugates for cancer immunotherapy. Proc Natl Acad Sci U S A 97, 9221-9225.

$\mathrm{Hu}, \mathrm{Z}$., and Garen, A. (2001). Targeting tissue factor on tumor vascular endothelial cells and tumor cells for immunotherapy in mouse models of prostatic cancer. Proc Natl Acad Sci U S A 98, 12180-12185.

$\mathrm{Hu}, \mathrm{Z}$., and Li, J. (2010). Natural killer cells are crucial for the efficacy of Icon (factor VII/human IgG1 Fc) immunotherapy in human tongue cancer. BMC Immunol 11, 49.

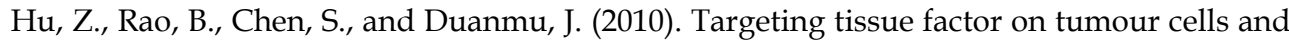
angiogenic vascular endothelial cells by factor VII-targeted verteporfin photodynamic therapy for breast cancer in vitro and in vivo in mice. BMC Cancer 10, 235.

$\mathrm{Hu}, \mathrm{Z}$., Rao, B., Chen, S., and Duanmu, J. (2011). Selective and effective killing of angiogenic vascular endothelial cells and cancer cells by targeting tissue factor using a factor VII-targeted photodynamic therapy for breast cancer. Breast Cancer Res Treat 126, 589-600. 
Hu, Z., Sun, Y., and Garen, A. (1999). Targeting tumor vasculature endothelial cells and tumor cells for immunotherapy of human melanoma in a mouse xenograft model. Proc Natl Acad Sci U S A 96, 8161-8166.

Hussong, J.W., Rodgers, G.M., and Shami, P.J. (2000). Evidence of increased angiogenesis in patients with acute myeloid leukemia. Blood 95, 309-313.

Idusogie, E., Rosen, E., Geng, J.P., Carmeliet, P., Collen, D., and Castellino, F.J. (1996a). Characterization of a cDNA encoding murine coagulation factor VII. Thrombosis and haemostasis 75, 481-487.

Idusogie, E., Rosen, E.D., Carmeliet, P., Collen, D., and Castellino, F.J. (1996b). Nucleotide structure and characterization of the murine blood coagulation factor VII gene. Thrombosis and haemostasis 76, 957-964.

Iijima, K., Fukuda, C., and Nakamura, K. (1991). Measurements of tissue factor-like activity in plasma of patients with DIC. Thrombosis research 61, 29-38.

Kageshita, T., Funasaka, Y., Ichihashi, M., Wakamatsu, K., Ito, S., and Ono, T. (2001). Tissue factor expression and serum level in patients with melanoma does not correlate with disease progression. Pigment Cell Res 14, 195-200.

Kaido, T., Oe, H., Yoshikawa, A., Mori, A., Arii, S., and Imamura, M. (2005). Tissue factor is a useful prognostic factor of recurrence in hepatocellular carcinoma in 5-year survivors. Hepato-gastroenterology 52, 1383-1387.

Kakkar, A.K., Lemoine, N.R., Scully, M.F., Tebbutt, S., and Williamson, R.C. (1995a). Tissue factor expression correlates with histological grade in human pancreatic cancer. The British journal of surgery 82, 1101-1104.

Kakkar, A.K., Lemoine, N.R., Stone, S.R., Altieri, D., and Williamson, R.C. (1995b). Identification of a thrombin receptor with factor Xa receptor and tissue factor in human pancreatic carcinoma cells. Clinical molecular pathology 48, M288-M290.

Kaushal, V., Mukunyadzi, P., Siegel, E.R., Dennis, R.A., Johnson, D.E., and Kohli, M. (2008). Expression of tissue factor in prostate cancer correlates with malignant phenotype. Appl Immunohistochem Mol Morphol 16, 1-6.

Keller, T., Salge, U., Konig, H., Dodt, J., Heiden, M., and Seitz, R. (2001). Tissue factor is the only activator of coagulation in cultured human lung cancer cells. Lung cancer (Amsterdam, Netherlands) 31, 171-179.

Khorana, A.A., Ahrendt, S.A., Ryan, C.K., Francis, C.W., Hruban, R.H., Hu, Y.C., Hostetter, G., Harvey, J., and Taubman, M.B. (2007). Tissue factor expression, angiogenesis, and thrombosis in pancreatic cancer. Clin Cancer Res 13, 2870-2875.

Khorana, A.A., and Fine, R.L. (2004). Pancreatic cancer and thromboembolic disease. The lancet oncology 5, 655-663.

Knowles, B.B., Howe, C.C., and Aden, D.P. (1980). Human hepatocellular carcinoma cell lines secrete the major plasma proteins and hepatitis B surface antigen. Science (New York, NY 209, 497-499.

Konigsberg, W.H., and Nemerson, Y. (1988). Molecular cloning of the cDNA for human tissue factor. Cell 52, 639-640.

Koomagi, R., and Volm, M. (1998). Tissue-factor expression in human non-small-cell lung carcinoma measured by immunohistochemistry: correlation between tissue factor and angiogenesis. International journal of cancer 79, 19-22. 
Korkolopoulou, P., Viniou, N., Kavantzas, N., Patsouris, E., Thymara, I., Pavlopoulos, P.M., Terpos, E., Stamatopoulos, K., Plata, E., Anargyrou, K., et al. (2003). Clinicopathologic correlations of bone marrow angiogenesis in chronic myeloid leukemia: a morphometric study. Leukemia 17, 89-97.

Krikun, G., Hu, Z., Osteen, K., Bruner-Tran, K.L., Schatz, F., Taylor, H.S., Toti, P., Arcuri, F., Konigsberg, W., Garen, A., et al. (2010). The immunoconjugate "icon" targets aberrantly expressed endothelial tissue factor causing regression of endometriosis. Am J Pathol 176, 1050-1056.

Kubota, T., Andoh, K., Sadakata, H., Tanaka, H., and Kobayashi, N. (1991). Tissue factor released from leukemic cells. Thrombosis and haemostasis 65, 59-63.

Lacal, P.M., Failla, C.M., Pagani, E., Odorisio, T., Schietroma, C., Falcinelli, S., Zambruno, G., and D'Atri, S. (2000). Human melanoma cells secrete and respond to placenta growth factor and vascular endothelial growth factor. J Invest Dermatol 115, 10001007.

Langer, F., Chun, F.K., Amirkhosravi, A., Friedrich, M., Leuenroth, S., Eifrig, B., Bokemeyer, C., and Francis, J.L. (2007). Plasma tissue factor antigen in localized prostate cancer: distribution, clinical significance and correlation with haemostatic activation markers. Thrombosis and haemostasis 97, 464-470.

Lindahl, A.K., Boffa, M.C., and Abildgaard, U. (1993). Increased plasma thrombomodulin in cancer patients. Thrombosis and haemostasis 69, 112-114.

Lindahl, A.K., Odegaard, O.R., Sandset, P.M., and Harbitz, T.B. (1992). Coagulation inhibition and activation in pancreatic cancer. Changes during progress of disease. Cancer 70, 2067-2072.

Litwin, C., Leong, K.G., Zapf, R., Sutherland, H., Naiman, S.C., and Karsan, A. (2002). Role of the microenvironment in promoting angiogenesis in acute myeloid leukemia. Am J Hematol 70, 22-30.

Lopez-Terrada, D., Cheung, S.W., Finegold, M.J., and Knowles, B.B. (2009). Hep G2 is a hepatoblastoma-derived cell line. Hum Pathol 40, 1512-1515.

Lu, F., Hu, Z., Sinard, J., Garen, A., and Adelman, R.A. (2009). Factor VII-verteporfin for targeted photodynamic therapy in a rat model of choroidal neovascularization. Invest Ophthalmol Vis Sci 50, 3890-3896.

Lwaleed, B.A., Francis, J.L., and Chisholm, M. (2000). Urinary tissue factor levels in patients with bladder and prostate cancer. Eur J Surg Oncol 26, 44-49.

Mayo, G.L., Melendez, R.F., Kumar, N., McKinnon, S.J., and Glickman, R.D. (2003). Antibody-targeted photodynamic therapy. American journal of ophthalmology $136,1151-1152$.

McDonald, D.M., and Choyke, P.L. (2003). Imaging of angiogenesis: from microscope to clinic. Nature medicine 9, 713-725.

Merlin, J.L., Gautier, H., Barberi-Heyob, M., Teiten, M.H., and Guillemin, F. (2003). The multidrug resistance modulator SDZ-PSC 833 potentiates the photodynamic activity of chlorin e6 independently of P-glycoprotein in multidrug resistant human breast adenocarcinoma cells. International journal of oncology 22, 733-739.

Milsom, C., and Rak, J. (2008). Tissue factor and cancer. Pathophysiol Haemost Thromb 36, 160-176. 
Minamiya, Y., Matsuzaki, I., Sageshima, M., Saito, H., Taguchi, K., Nakagawa, T., and Ogawa, J. (2004). Expression of tissue factor mRNA and invasion of blood vessels by tumor cells in non-small cell lung cancer. Surgery today 34, 1-5.

Morrissey, J.H., Fakhrai, H., and Edgington, T.S. (1987). Molecular cloning of the cDNA for tissue factor, the cellular receptor for the initiation of the coagulation protease cascade. Cell 50, 129-135.

Nakasaki, T., Wada, H., Mori, Y., Okugawa, Y., Watanabe, R., Nishikawa, M., Gabazza, E.C., Masuya, M., Kageyama, S., Kumeda, K., et al. (2000a). Decreased tissue factor and tissue-plasminogen activator antigen in relapsed acute promyelocytic leukemia. Am J Hematol 64, 145-150.

Nakasaki, T., Wada, H., Shigemori, C., Miki, C., Gabazza, E.C., Nobori, T., Nakamura, S., and Shiku, H. (2002). Expression of tissue factor and vascular endothelial growth factor is associated with angiogenesis in colorectal cancer. Am J Hematol 69, 247254.

Nakasaki, T., Wada, H., Watanabe, R., Mori, Y., Gabazza, E.C., Kageyama, S., Nishikawa, M., and Shiku, H. (2000b). Elevated tissue factor levels in leukemic cell homogenate. Clin Appl Thromb Hemost 6, 14-17.

Nieva, J. (2007). The clinical significance of circulating tissue factor in prostate cancer. Thrombosis and haemostasis 97, 329-330.

Nitori, N., Ino, Y., Nakanishi, Y., Yamada, T., Honda, K., Yanagihara, K., Kosuge, T., Kanai, Y., Kitajima, M., and Hirohashi, S. (2005). Prognostic significance of tissue factor in pancreatic ductal adenocarcinoma. Clin Cancer Res 11, 2531-2539.

O'Hara, P.J., Grant, F.J., Haldeman, B.A., Gray, C.L., Insley, M.Y., Hagen, F.S., and Murray, M.J. (1987). Nucleotide sequence of the gene coding for human factor VII, a vitamin K-dependent protein participating in blood coagulation. Proceedings of the National Academy of Sciences of the United States of America 84, 5158-5162.

Ohta, S., Wada, H., Nakazaki, T., Maeda, Y., Nobori, T., Shiku, H., Nakamura, S., Nagakawa, O., Furuya, Y., and Fuse, H. (2002). Expression of tissue factor is associated with clinical features and angiogenesis in prostate cancer. Anticancer Res 22, 2991-2996.

Oleinick, N.L., and Evans, H.H. (1998). The photobiology of photodynamic therapy: cellular targets and mechanisms. Radiat Res 150, S146-156.

Osterud, B. (1997). Tissue factor: a complex biological role. Thrombosis and haemostasis 78 , 755-758.

Padro, T., Ruiz, S., Bieker, R., Burger, H., Steins, M., Kienast, J., Buchner, T., Berdel, W.E., and Mesters, R.M. (2000). Increased angiogenesis in the bone marrow of patients with acute myeloid leukemia. Blood 95, 2637-2644.

Park, J.G., Lee, J.H., Kang, M.S., Park, K.J., Jeon, Y.M., Lee, H.J., Kwon, H.S., Park, H.S., Yeo, K.S., Lee, K.U., et al. (1995). Characterization of cell lines established from human hepatocellular carcinoma. International journal of cancer 62, 276-282.

Perez-Atayde, A.R., Sallan, S.E., Tedrow, U., Connors, S., Allred, E., and Folkman, J. (1997). Spectrum of tumor angiogenesis in the bone marrow of children with acute lymphoblastic leukemia. Am J Pathol 150, 815-821. 
Poon, R.T., Lau, C.P., Ho, J.W., Yu, W.C., Fan, S.T., and Wong, J. (2003). Tissue factor expression correlates with tumor angiogenesis and invasiveness in human hepatocellular carcinoma. Clin Cancer Res 9, 5339-5345.

Pule, M.A., Gullmann, C., Dennis, D., McMahon, C., Jeffers, M., and Smith, O.P. (2002). Increased angiogenesis in bone marrow of children with acute lymphoblastic leukaemia has no prognostic significance. Br J Haematol 118, 991-998.

Rak, J., Milsom, C., May, L., Klement, P., and Yu, J. (2006). Tissue factor in cancer and angiogenesis: the molecular link between genetic tumor progression, tumor neovascularization, and cancer coagulopathy. Semin Thromb Hemost 32, 54-70.

Rak, J., Milsom, C., and Yu, J. (2008). Tissue factor in cancer. Curr Opin Hematol 15, 522-528.

Rao, L.V., and Pendurthi, U.R. (1998). Tissue factor on cells. Blood Coagul Fibrinolysis 9 Suppl 1, S27-35.

Rauch, U., Antoniak, S., Boots, M., Schulze, K., Goldin-Lang, P., Stein, H., Schultheiss, H.P., and Coupland, S.E. (2005). Association of tissue-factor upregulation in squamouscell carcinoma of the lung with increased tissue factor in circulating blood. The lancet oncology 6, 254.

Rickles, F.R., and Brenner, B. (2008). Tissue factor and cancer. Semin Thromb Hemost 34, 143-145.

Rickles, F.R., Hair, G.A., Zeff, R.A., Lee, E., and Bona, R.D. (1995). Tissue factor expression in human leukocytes and tumor cells. Thrombosis and haemostasis 74, 391-395.

Rickles, F.R., Patierno, S., and Fernandez, P.M. (2003). Tissue factor, thrombin, and cancer. Chest 124, 58S-68S.

Romanque, P., Piguet, A.C., and Dufour, J.F. (2008). Targeting vessels to treat hepatocellular carcinoma. Clin Sci (Lond) 114, 467-477.

Rouhi, P., Lee, S.L., Cao, Z., Hedlund, E.M., Jensen, L.D., and Cao, Y. (2010). Pathological angiogenesis facilitates tumor cell dissemination and metastasis. Cell Cycle 9, 913917.

Ruf, W., and Mueller, B.M. (1996). Tissue factor in cancer angiogenesis and metastasis. Curr Opin Hematol 3, 379-384.

Ruf, W., Yokota, N., and Schaffner, F. (2010). Tissue factor in cancer progression and angiogenesis. Thrombosis research 125 Suppl 2, S36-38.

Salge, U., Seitz, R., Wimmel, A., Schuermann, M., Daubner, E., and Heiden, M. (2001). Transition from suspension to adherent growth is accompanied by tissue factor expression and matrix metalloproteinase secretion in a small cell lung cancer cell line. Journal of cancer research and clinical oncology 127, 139-141.

Sawada, M., Miyake, S., Ohdama, S., Matsubara, O., Masuda, S., Yakumaru, K., and Yoshizawa, Y. (1999). Expression of tissue factor in non-small-cell lung cancers and its relationship to metastasis. British journal of cancer 79, 472-477.

Schabbauer, G., Schweighofer, B., Mechtcheriakova, D., Lucerna, M., Binder, B.R., and Hofer, E. (2007). Nuclear factor of activated T cells and early growth response-1 cooperate to mediate tissue factor gene induction by vascular endothelial growth factor in endothelial cells. Thrombosis and haemostasis 97, 988-997.

Semeraro, N., and Colucci, M. (1997). Tissue factor in health and disease. Thrombosis and haemostasis $78,759-764$. 
Sharman, W.M., van Lier, J.E., and Allen, C.M. (2004). Targeted photodynamic therapy via receptor mediated delivery systems. Advanced drug delivery reviews 56, 53-76.

Shen, B.Q., Lee, D.Y., Cortopassi, K.M., Damico, L.A., and Zioncheck, T.F. (2001). Vascular endothelial growth factor KDR receptor signaling potentiates tumor necrosis factorinduced tissue factor expression in endothelial cells. The Journal of biological chemistry 276, 5281-5286.

Shigemori, C., Wada, H., Matsumoto, K., Shiku, H., Nakamura, S., and Suzuki, H. (1998). Tissue factor expression and metastatic potential of colorectal cancer. Thrombosis and haemostasis 80, 894-898.

Shoji, M., Hancock, W.W., Abe, K., Micko, C., Casper, K.A., Baine, R.M., Wilcox, J.N., Danave, I., Dillehay, D.L., Matthews, E., et al. (1998). Activation of coagulation and angiogenesis in cancer: immunohistochemical localization in situ of clotting proteins and vascular endothelial growth factor in human cancer. Am J Pathol 152, 399-411.

Shoji, M., Sun, A., Kisiel, W., Lu, Y.J., Shim, H., McCarey, B.E., Nichols, C., Parker, E.T., Pohl, J., Mosley, C.A., et al. (2008). Targeting tissue factor-expressing tumor angiogenesis and tumors with EF24 conjugated to factor VIIa. J Drug Target 16, 185-197.

Silberberg, J.M., Gordon, S., and Zucker, S. (1989). Identification of tissue factor in two human pancreatic cancer cell lines. Cancer research 49, 5443-5447.

Spicer, E.K., Horton, R., Bloem, L., Bach, R., Williams, K.R., Guha, A., Kraus, J., Lin, T.C., Nemerson, Y., and Konigsberg, W.H. (1987). Isolation of cDNA clones coding for human tissue factor: primary structure of the protein and cDNA. Proceedings of the National Academy of Sciences of the United States of America 84, 5148-5152.

Sturm, U., Luther, T., Albrecht, S., Flossel, C., Grossmann, H., and Muller, M. (1992). Immunohistological detection of tissue factor in normal and abnormal human mammary glands using monoclonal antibodies. Virchows Arch A Pathol Anat Histopathol 421, 79-86.

Taber, S.W., Fingar, V.H., and Wieman, T.J. (1998). Photodynamic therapy for palliation of chest wall recurrence in patients with breast cancer. J Surg Oncol 68, 209-214.

Takano, S., Tsuboi, K., Tomono, Y., Mitsui, Y., and Nose, T. (2000). Tissue factor, osteopontin, alphavbeta3 integrin expression in microvasculature of gliomas associated with vascular endothelial growth factor expression. British journal of cancer 82, 1967-1973.

Tanaka, H., Narahara, N., Kurabayashi, H., Sadakata, H., Andoh, K., Uchiyama, T., Kobayashi, N., and Maekawa, T. (1989). Studies on leukemic cell tissue factor. Thrombosis research 53, 535-549.

Tanaka, M. (1989). Induction of tissue factor-like activity of human monoblastic leukemia cell line by tumor necrosis factor-alpha. Thrombosis research 56, 201-211.

Tanaka, M., and Kishi, T. (1990). Induction of tissue factor by interleukin-2 in acute myelogenous leukemia (AML) cells. Growth Factors 4, 1-8.

Tanaka, M., and Yamanishi, H. (1993). The expression of tissue factor antigen and activity on the surface of leukemic cells. Leuk Res 17, 103-111. 
Tang, Y., Borgstrom, P., Maynard, J., Koziol, J., Hu, Z., Garen, A., and Deisseroth, A. (2007). Mapping of angiogenic markers for targeting of vectors to tumor vascular endothelial cells. Cancer Gene Ther 14, 346-353.

Taniguchi, T., Kakkar, A.K., Tuddenham, E.G., Williamson, R.C., and Lemoine, N.R. (1998). Enhanced expression of urokinase receptor induced through the tissue factor-factor VIIa pathway in human pancreatic cancer. Cancer research 58, 4461-4467.

Tesselaar, M.E., Romijn, F.P., Van Der Linden, I.K., Prins, F.A., Bertina, R.M., and Osanto, S. (2007). Microparticle-associated tissue factor activity: a link between cancer and thrombosis? J Thromb Haemost 5, 520-527.

Tezel, T.H., Bodek, E., Sonmez, K., Kaliappan, S., Kaplan, H.J., Hu, Z., and Garen, A. (2007). Targeting tissue factor for immunotherapy of choroidal neovascularization by intravitreal delivery of factor VII-Fc chimeric antibody. Ocul Immunol Inflamm 15, 3-10.

Thomas, D.A., Giles, F.J., Cortes, J., Albitar, M., and Kantarjian, H.M. (2001). Antiangiogenic therapy in leukemia. Acta Haematol 106, 190-207.

Ueda, C., Hirohata, Y., Kihara, Y., Nakamura, H., Abe, S., Akahane, K., Okamoto, K., Itoh, H., and Otsuki, M. (2001). Pancreatic cancer complicated by disseminated intravascular coagulation associated with production of tissue factor. Journal of gastroenterology 36, 848-850.

Ueno, T., Toi, M., Koike, M., Nakamura, S., and Tominaga, T. (2000). Tissue factor expression in breast cancer tissues: its correlation with prognosis and plasma concentration. British journal of cancer 83, 164-170.

Uno, K., Homma, S., Satoh, T., Nakanishi, K., Abe, D., Matsumoto, K., Oki, A., Tsunoda, H., Yamaguchi, I., Nagasawa, T., et al. (2007). Tissue factor expression as a possible determinant of thromboembolism in ovarian cancer. British journal of cancer 96, 290-295.

Wang, B., Berger, M., Masters, G., Albone, E., Yang, Q., Sheedy, J., Kirksey, Y., Grimm, L., Wang, B., Singleton, J., et al. (2005). Radiotherapy of human xenograft NSCLC tumors in nude mice with a 90Y-labeled anti-tissue factor antibody. Cancer biotherapy \& radiopharmaceuticals 20, 300-309.

Watanabe, Y., Lee, S.W., Detmar, M., Ajioka, I., and Dvorak, H.F. (1997). Vascular permeability factor/vascular endothelial growth factor (VPF/VEGF) delays and induces escape from senescence in human dermal microvascular endothelial cells. Oncogene 14, 2025-2032.

Weidner, N., Semple, J.P., Welch, W.R., and Folkman, J. (1991). Tumor angiogenesis and metastasis--correlation in invasive breast carcinoma. N Engl J Med 324, 1-8.

Yang, R., and Han, Z.C. (2002). Angiogenesis in hematologic malignancies and its clinical implications. Int J Hematol 75, 246-256.

Yokota, N., Koizume, S., Miyagi, E., Hirahara, F., Nakamura, Y., Kikuchi, K., Ruf, W., Sakuma, Y., Tsuchiya, E., and Miyagi, Y. (2009). Self-production of tissue factorcoagulation factor VII complex by ovarian cancer cells. Br J Cancer 101, 2023-2029.

Zacharski, L.R., Schned, A.R., and Sorenson, G.D. (1983). Occurrence of fibrin and tissue factor antigen in human small cell carcinoma of the lung. Cancer research 43, 39633968. 
Zetter, B.R. (1998). Angiogenesis and tumor metastasis. Annu Rev Med 49, 407-424.

Zucker, S., Mirza, H., Conner, C.E., Lorenz, A.F., Drews, M.H., Bahou, W.F., and Jesty, J. (1998). Vascular endothelial growth factor induces tissue factor and matrix metalloproteinase production in endothelial cells: conversion of prothrombin to thrombin results in progelatinase A activation and cell proliferation. International journal of cancer $75,780-786$. 


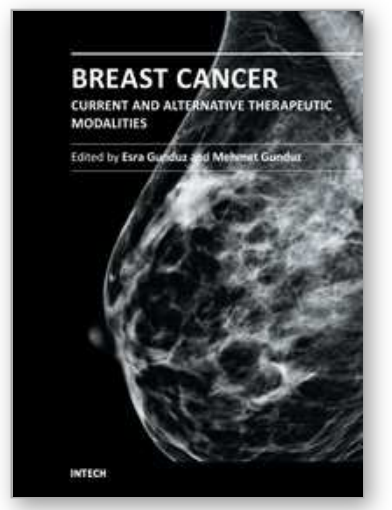

\author{
Breast Cancer - Current and Alternative Therapeutic Modalities \\ Edited by Prof. Esra Gunduz
}

ISBN 978-953-307-776-5

Hard cover, 540 pages

Publisher InTech

Published online 09, November, 2011

Published in print edition November, 2011

Cancer is the leading cause of death in most countries and its consequences result in huge economic, social and psychological burden. Breast cancer is the most frequently diagnosed cancer type and the leading cause of cancer death among females. In this book, we discussed various therapeutic modalities from signaling pathways through various anti-tumor compounds as well as herbal medicine for this deadly cancer. We hope that this book will contribute to the development of novel diagnostic as well as therapeutic approaches.

\title{
How to reference
}

In order to correctly reference this scholarly work, feel free to copy and paste the following:

Zhiwei Hu (2011). Factor VII-Targeted Photodynamic Therapy for Breast Cancer and Its Therapeutic Potential for Other Solid Cancers and Leukemia, Breast Cancer - Current and Alternative Therapeutic Modalities, Prof. Esra Gunduz (Ed.), ISBN: 978-953-307-776-5, InTech, Available from:

http://www.intechopen.com/books/breast-cancer-current-and-alternative-therapeutic-modalities/factor-viitargeted-photodynamic-therapy-for-breast-cancer-and-its-therapeutic-potential-for-other-s

\section{INTECH}

open science | open minds

\section{InTech Europe}

University Campus STeP Ri

Slavka Krautzeka 83/A

51000 Rijeka, Croatia

Phone: +385 (51) 770447

Fax: +385 (51) 686166

www.intechopen.com

\section{InTech China}

Unit 405, Office Block, Hotel Equatorial Shanghai

No.65, Yan An Road (West), Shanghai, 200040, China

中国上海市延安西路65号上海国际贵都大饭店办公楼 405 单元

Phone: +86-21-62489820

Fax: +86-21-62489821 
(C) 2011 The Author(s). Licensee IntechOpen. This is an open access article distributed under the terms of the Creative Commons Attribution 3.0 License, which permits unrestricted use, distribution, and reproduction in any medium, provided the original work is properly cited. 